\title{
Warunki bytu w polskich gospodarstwach domowych dotkniętych ubóstwem
}

\section{Wprowadzenie}

Okres transformacji gospodarczej dokonującej się w Polsce od ponad dziesięciu lat skłania do przeprowadzenia oceny skutków tych procesów. Przemiany ustrojowe przyniosły bowiem wolność, ale obnażyły ubóstwo części polskich rodzin. Powrót do gospodarki rynkowej, upadek totalitaryzmu i reformy przeprowadzane w pionierski sposób spowodowały, że kraj znalazł się w bardzo trudnej sytuacji. Wszystkie te procesy odcisnęły piętno na warunkach bytu polskich rodzin $\mathrm{w}$ znaczny sposób. Znalazło to odbicie przede wszystkim w większym zróżnicowaniu dochodów i nierówności społecznych.

Nierówności społeczne w sferze konsumpcji są zjawiskiem wielowymiarowym. Do wskaźników opisujących to zjawisko należą m.in. dochody przypadające na jedną osobę w określonej grupie społecznej lub w obrębie grupy. Ważne są również otoczenie gospodarstwa domowego (środowisko naturalne, bezpieczeństwo) oraz warunki mieszkaniowe, poziom wykształcenia i możliwość dalszej edukacji, nie tylko na poziomie podstawowym, ale również kształcenie permanentne w okresie życia zawodowego. Szczególnego znaczenia nabiera również dostępność do rynku pracy. Możliwości zatrudnienia i uzyskiwania wyższych dochodów skorelowane są najbardziej z poziomem wykształcenia. Uzupełnieniem sq̨ dostępność do instytucji kulturalnych i uczestnictwo w kulturze, zgromadzone zasoby dóbr, zwłaszcza ułatwiające zwiększenie wymiaru wolnego czasu i dostępu do szeroko rozumianej informacji.

W opracowaniu, w celu przedstawienia warunków życia gospodarstw domowych żyjących $w$ sferze ubóstwa, przeprowadzono analizę zróżnicowania dochodów i wydatków ubogich rodzin ${ }^{1}$. W tym celu wykorzystano proste metody opisu statystycznego, takie jak miary położenia (średnia arytmetyczna) i miary zmienności (współczynnik zmienności).

\footnotetext{
'Występujący w opracowaniu termin „rodzina" odpowiada pojęciu „gospodarstwo domowe”.
} 


\section{Zróźnicowanie dochodowe gospodarstw domowych żyjących w ubóstwie}

Jednym $\mathrm{z}$ ważniejszych czynników determinujących konsumpcję gospodarstwa domowego są dochody. Ich wielkość w przeliczeniu na jedną osobę $\mathrm{w}$ rodzinie jest jednym $\mathrm{z}$ determinantów szeroko pojmowanej kondycji gospodarstwa domowego.

W odniesieniu do sfery ubóstwa fundamentalne znaczenie mają granice (linie) oddzielające ubogie gospodarstwa domowe od innych gospodarstw w kraju. Wewnątrz sfery ubóstwa również występuje dalszy podział na dwie zasadnicze grupy, tj. na ubóstwo skrajne, do którego zaliczane są gospodarstwa domowe osiagające dochody poniżej minimum egzystencji, oraz na ubóstwo materialne, do którego zaliczane są gospodarstwa domowe osiagajace dochody poniżej minimum socjalnego.

Standard minimum socjalnego można oceniać przez siłę nabywczą dochodu odpowiadającego tej kategorii lub - inaczej - z punktu widzenia możliwości zaspokajania podstawowych potrzeb, co zostanie omówione niżej. Istotne znaczenie w tej ocenie może mieć również analiza relacji wydatków do dochodu przeciętnego wynikającego $\mathrm{z}$ podziału $\mathrm{PKB}$, przeciętnego lub najniższego wynagrodzenia oraz przeciętnej lub najniższej emerytury. Porównania takie przedstawiono w tabeli 1.

Uwagę zwraca przede wszystkim relacja minimum socjalnego do przeciętnego dochodu dyspozycyjnego przypadającego na 1 mieszkańca (według rachunków narodowych) $)^{2}$. Z przedstawionych relacji wynika m.in., że w $1994 \mathrm{r}$. minimum socjalne dla 1-osobowego gospodarstwa wynosiło średnio $3 / 4$ dochodu do dyspozycji. W latach następnych relacja ta wykazywała wzrost. W 2001 r. minimum socjalne stanowiło ponad $80 \%$ dochodu do dyspozycji ${ }^{3}$. Gdyby względna linia ubóstwa była wyznaczana na poziomie połowy przeciętnego dochodu do dyspozycji, to minimum socjalne byłoby dość bliskie tak określonego miernika.

Inaczej kształtuje się poziom minimum socjalnego w porównaniu z przeciętnymi dochodami rozporządzalnymi gospodarstw domowych. Dzieje się tak dlatego, że przeciętny dochód rozporządzalny jest $\mathrm{w}$ przybliżeniu 0 niższy od przeciętnego dochodu do dyspozycji ${ }^{4}$. I tak, minimum socjalne dla

\footnotetext{
${ }^{2}$ Dochód do dyspozycji przeznaczony jest na sfinansowanie konsumpcji gospodarstwa domowego oraz na oszczędności.

${ }^{3}$ Wobec braku danych o dochodach do dyspozycji w latach 1994-2000 nie uwzględniono odpowiedniej relacji w tabeli 1.

${ }^{4}$ Różnica ta tylko częściowo daje się wyjaśnić odmiennym zakresem i metodą badania każdej $\mathrm{z}$ tych kategorii. W części jednak te różnice można wiązać $\mathrm{z}$ powszechnie występującym zjawi-
} 
Tabela 1

Relacje minimum socjalnego dla 1-osobowych gospodarstw domowych do wybranych kategorii dochodów (kategorie dochodów $=100,0$ )

\begin{tabular}{|c|c|c|c|c|c|c|c|c|}
\hline \multirow[t]{3}{*}{ Kategorie dochodów } & \multicolumn{8}{|c|}{ Lata } \\
\hline & 1994 & 1995 & 1996 & 1997 & 1998 & 1999 & 2000 & 2001 \\
\hline & \multicolumn{8}{|c|}{ Minimum socjalne gospodarstw domowych osób do 60 lat } \\
\hline $\begin{array}{l}\text { 1. Przeciętny dochód do } \\
\text { dyspozycji na } 1 \text { miesz- } \\
\text { kańca }\end{array}$ & 76 & - & - & - & - & - & - & 82 \\
\hline $\begin{array}{l}\text { 2. Przeciętny dochód } \\
\text { rozporządzalny w go- } \\
\text { spodarstwie domowym }\end{array}$ & 109 & 110,8 & 106 & 109,8 & 108,2 & 113,8 & 106,3 & 117,6 \\
\hline $\begin{array}{l}\text { 3. Przeciętne wynagro- } \\
\text { dzenie (brutto) }\end{array}$ & 48,1 & 48,1 & 46,3 & 45,5 & 45,9 & 37,5 & 36,6 & 37,0 \\
\hline $\begin{array}{l}\text { 3a. Przeciętne wyna- } \\
\text { grodzenie (netto) }\end{array}$ & 59,3 & 59,4 & 57,1 & 55,2 & 55,1 & - & - & - \\
\hline 4. Placa minimalna & 137 & - & 132 & - & - & - & - & - \\
\hline 5. Minimum egzystencji & 213,9 & 217,2 & 224,7 & $x$ & 222,8 & 219,2 & 222,9 & 225,8 \\
\hline \multicolumn{9}{|c|}{ Minimum socjalne gospodarstw domowych osób powyżej 60 lat } \\
\hline $\begin{array}{l}\text { 1. Przeciętny dochód do } \\
\text { dyspozycji na } 1 \text { miesz- } \\
\text { kańca }\end{array}$ & 66 & - & - & - & - & - & - & - \\
\hline $\begin{array}{l}\text { 2. Przeciettny dochód } \\
\text { rozporządzalny w go- } \\
\text { spodarstwie domowym }\end{array}$ & 95 & 100,1 & 92,7 & 100,1 & 99,6 & 105,0 & 105,0 & 108,6 \\
\hline $\begin{array}{l}\text { 3. Przeciętna emerytura } \\
\text { i renta pracownicza } \\
\text { (brutto) }\end{array}$ & 65,1 & 68,5 & 66,4 & 69,2 & 71,1 & 72,3 & 73,2 & 72,0 \\
\hline $\begin{array}{l}\text { 3a. Przeciętna emerytu- } \\
\text { ra i renta pracownicza } \\
\text { (netto) }\end{array}$ & 78 & 82,5 & 80 & 81,7 & 82,8 & - & - & - \\
\hline $\begin{array}{l}\text { 4. Najniższa emerytura } \\
\text { i renta rodzinna }\end{array}$ & 140 & - & 145 & - & - & - & - & - \\
\hline 5. Minimum egzystencji & 193,7 & 202,3 & 200,5 & - & 209,2 & 209,6 & 208,7 & 211,5 \\
\hline
\end{tabular}

"Dane od 1999 r. obejmują wynagrodzenia brutto.

*:Dane od 1999 roku obejmują emerytury i renty brutto.

Źródlo: Obliczenia własne na podstawie Roczników Statystycznych GUS za lata 1995-2002.

skiem zaniżania informacji o dochodach przez respondentów badań buđżetowych, a także stosunkowo dużą liczbą gospodarstw odmawiających uczestnictwa w badaniach. Wśród odmawiających znaczny odsetek stanowią gospodarstwa osób pracujących na rachunek własny oraz pracujących najemnie, a więc $\mathrm{z}$ grup gospodarstw o relatywnie wyższych dochodach; jest prawdopodobne, że gospodarstwa o bardzo niskich dochodach też odmawiają udziału w badaniach. 
l-osobowego gospodarstwa osoby do 60. roku życia stanowiło w analizowanym okresie ok. $110 \%$ przeciętnego dochodu rozporządzalnego obliczonego dla ogólu gospodarstw domowych. Z kolei minimum socjalne dla l-osobowego gospodarstwa osób starszych (po 60. roku życia) było niższe od przeciętnego dochodu rozporządzalnego gospodarstw domowych emerytów i rencistów w 1994 r. o 5\%, a w 1996 r. o 7\%. Od 1999 r. tendencja ta uległa zmianie. Wysokość minimum socjalnego przewyższała przeciętny dochód rozporządzalny średnio o $5 \%$ (tab. 2).

\section{Tabela 2}

Relacje minimum egzystencji dla 1-osobowych gospodarstw domowych do wybranych kategorii dochodów (kategorie dochodów $=100,0$ )

\begin{tabular}{|c|c|c|c|c|c|c|c|c|}
\hline \multirow[t]{3}{*}{ Kategorie dochodów } & \multicolumn{8}{|c|}{ Lata } \\
\hline & 1994 & 1995 & 1996 & 1997 & 1998 & 1999 & 2000 & 2001 \\
\hline & \multicolumn{8}{|c|}{$\begin{array}{l}\text { Minimum egzystencji gospodarstw domowych osób do } \\
60 \text { lat }\end{array}$} \\
\hline $\begin{array}{l}\text { 1. Przeciętny dochód do } \\
\text { dyspozycji na } 1 \text { mieszkańca }\end{array}$ & - & - & - & - & - & - & - & 54,0 \\
\hline $\begin{array}{l}\text { 2. Przeciętny dochód rozpo- } \\
\text { rzadzalny w gospodarstwie } \\
\text { domowym }\end{array}$ & 51,1 & 51,0 & 47,0 & - & 48,5 & 51,9 & 51,0 & 52,0 \\
\hline $\begin{array}{l}\text { 3. Przeciętne wynagrodze- } \\
\text { nie (brutto)" }\end{array}$ & 22,4 & 22,1 & 20,6 & - & 20,6 & 14,9 & 16,4 & 16,4 \\
\hline $\begin{array}{l}\text { 3a. Przeciętne wynagro- } \\
\text { dzenie (netto) }\end{array}$ & 27,7 & 27,3 & 25,4 & - & 24,7 & - & - & - \\
\hline 4. Placa minimalna & 63,9 & - & 43,1 & - & - & - & - & - \\
\hline \multirow[t]{2}{*}{ 6. Minimum socjalne } & 46,7 & 46,0 & 44,4 & - & 44,8 & 45,6 & 44,7 & 44,2 \\
\hline & \multicolumn{8}{|c|}{$\begin{array}{c}\text { Minimum egzystencji gospodarstw domowych osób } \\
\text { powyżej } 60 \text { lat }\end{array}$} \\
\hline $\begin{array}{l}\text { 1. Przeciętny dochód rozpo- } \\
\text { rządzalny w gospodarstwie } \\
\text { domowym }\end{array}$ & 46,5 & 49,5 & 47,0 & $=$ & 47,6 & 51,2 & 50,3 & 51,3 \\
\hline $\begin{array}{l}\text { 2. Przeciętna emerytura } \\
\text { i renta pracownicza (brut- } \\
\text { to) }\end{array}$ & 33,6 & 33,9 & 33,1 & - & 33,9 & 35,2 & 35,0 & 34,0 \\
\hline $\begin{array}{l}\text { 2a. Przeciętna emerytura } \\
\text { i renta pracownicza (netto) }\end{array}$ & 40,4 & 40,8 & 39,7 & - & 39,6 & $=$ & - & - \\
\hline $\begin{array}{l}\text { 3. Najniższa emerytura } \\
\text { i renta rodzinna }\end{array}$ & 72,4 & & 72,1 & - & & & & \\
\hline 4. Minimum socjalne & 51,6 & 49,4 & 49,8 & - & 47,7 & 48,7 & 47,8 & 47,2 \\
\hline
\end{tabular}

"Dane od 1999 r. obejmuja wynagrodzenia brutto.

*:Dane od 1999 r. obejmują emerytury i renty brutto.

Źródło: Obliczenia własne na podstawie Roczników Statystycznych GUS za lata 1995-2002. 
W dwóch pierwszych latach objętych badaniem minimum socjalne stanowiło także blisko $60 \%$ przeciętnego wynagrodzenia w gospodarce narodowej. W latach kolejnych proporcja minimum socjalnego do tej kategorii dochodu ulegała niewielkiej obniżce. Ponadto, minimum socjalne $w$ analizowanym okresie przewyższało płacę minimalną o ponad $30 \%$ oraz było średnio niższe o około $20 \%$ od przeciętnej emerytury i renty (w gospodarstwach pracowniczych), a także przewyższało najniższą emeryturę i rentę rodzinną przeciętnie o ponad 40 punktów procentowych. Porównując $\mathrm{z}$ kolei standard minimum socjalnego $\mathrm{z}$ minimum egzystencji, widać, iż to pierwsze było ponaddwukrotnie wyższe od drugiego. Daje to wyraźne wyobrażenie o rozpiętości tych dwóch granic ubóstwa.

$\mathrm{Z}$ kolei $\mathrm{z}$ porównania danych o minimum egzystencji $\mathrm{z}$ danymi o przeciętnych dochodach rozporządzalnych oraz średnich $\mathrm{i}$ najniższych wynagrodzeniach wynika, iż $w$ analizowanym okresie minimum egzystencji (ustalane dla osób do 60 lat) było niższe $\mathrm{w}$ porównaniu $\mathrm{z}$ wszystkimi kategoriami dochodu objętymi badaniem. Było ono blisko dwukrotnie niższe od przeciętnego dochodu rozporządzalnego, prawie czterokrotnie niższe od przeciętnego wynagrodzenia w gospodarce i ponaddwukrotnie mniejsze od minimum socjalnego:

Podobne kształtowały się relacje minimum egzystencji w stosunku do przeciętnej i najniższej emerytury i renty pracowniczej (ujętych łącznie). Minimum to było około $60 \%$ niższe od przeciętnych świadczeń emerytalno-rentowych i około $30 \%$ od najniższych. Relacje te stanowią wymowną ilustracje niskiej relacji analizowanych kategorii dochodowych, a przede wszystkim najniższych wynagrodzeń i świadczeń emerytalno-rentowych. Ponadto zwraca uwage pogorszenie się w kolejnych latach wskaźników relacji minimum egzystencji dla osób starszych do dochodów z emerytur i rent, zwłaszcza najniższych świadczeń, na co niewątpliwie wpłynęła zmiana zasad ich waloryzacji $\mathrm{z}$,płacowej" na „cenowa".

\section{Zróżnicowanie wydatków ubogich gospodarstw domowych}

Niemożność zaspokojenia elementarnych potrzeb rodziny (wyżywienie, ochrona zdrowia, edukacja) spowodowana niskimi dochodami jest pierwszym, najbardziej odczuwalnym skutkiem ubóstwa. Ze statystyki badań budżetów gospodarstw domowych wynika, iż ubogie gospodarstwa domowe w Polsce charakteryzują się nie tylko niskim poziomem i niekorzystną strukturą spoży- 
cia, ale również nie najlepszymi warunkami mieszkaniowymi oraz gorszym wyposażeniem w dobra trwałego użytku 5 .

Warunki bytu gospodarstw domowych żyjących w sferze ubóstwa, w tym przede wszystkim poziom ich wydatków, sq̨ wyraźnie zróżnicowane w zależności od przyjętej granicy ubóstwa (rys. 1).

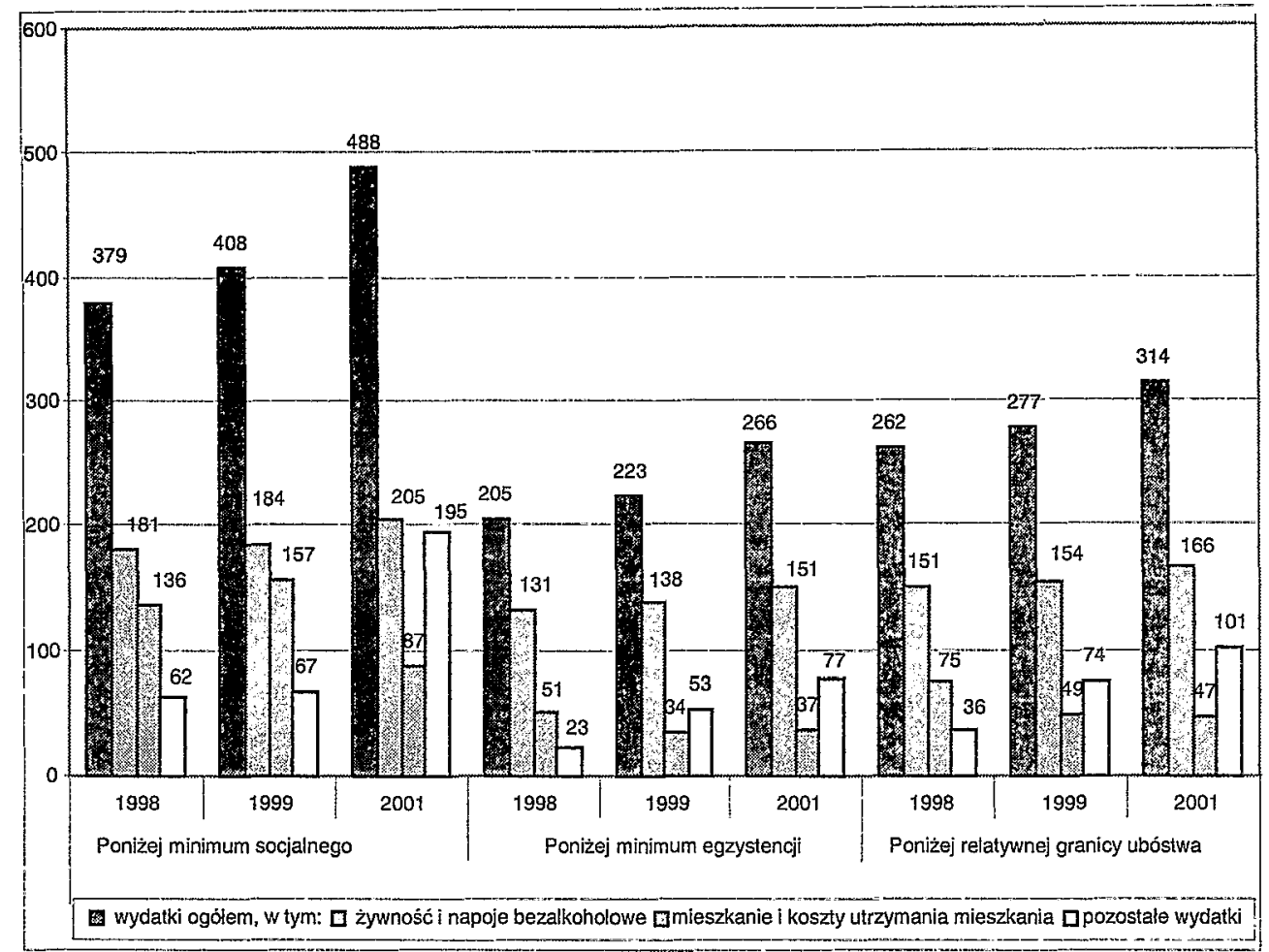

\section{Rysunek 1}

Wydatki gospodarstw domowych żyjących poniżej danej granicy ubóstwa (w zł na jednostkę ekwiwalentną"

"Z uwzględnieniem skali OECD. Podane wartości odpowiadają wysokości wydatków dla gospodarstw, jednoosobowych. Aby otrzymać wydatki dla większych gospodarstw należy przemnożyć podaną wartość przez liczbę jednostek ekwiwalentnych właściwą dla danego typu gospodarstw.

Żródło: Warunki życia ludności. GUS, Warszawa 1999, 2000.

Zgodnie z przedstawionymi danymi można stwierdzić, iż wraz z obniżaniem się progu ubóstwa zwiększa się deprawacja potrzeb gospodarstw domowych. W 1998 r. ogólny poziom wydatków gospodarstw domowych żyjących w sferze niedostatku był wyższy prawie o $46 \%$ od wydatków gospodarstw ży-

\footnotetext{
${ }^{5}$ Warunki życia ludności. GUS, Warszawa 1999, 2000.
} 
jących w skrajnym ubóstwie i o $31 \%$ większy od wydatków ponoszonych przez gospodarstwa domowe żyjące poniżej relatywnej granicy ubóstwa ${ }^{6}$. W latach następnych relacje te utrzymywały się na zbliżonym poziomie z niewielką tendencją rosnąca.

Analiza relacji między bezwzględną wielkością wydatków przeznaczanych na zaspokojenie podstawowych potrzeb przyjętych w konstruowanych modelach minimum a wysokością wydatków rzeczywistych pozwala na określenie dystansu, jaki dzieli rzeczywisty poziom zaspokojenia potrzeb rodzin ubogich od poziomu uznanego za minimalny. I tak, wydatki rodzin żyjących w sferze ubóstwa materialnego w 1998 r. były o $33 \%$ niższe od przyjętych założeń minimum socjalnego, a w $2001 \mathrm{r}$. już o $46 \%{ }^{7}$. Znacznie poniżej przyjętych norm kształtują się także wydatki rodzin żyjących w sferze ubóstwa skrajnego w 1998 r. o blisko $20 \%$, a w 2001 r. o $21 \%$.

Do wyraźniejszego pokazania zróżnicowania wielkości wydatków wśród ubogich gospodarstw domowych wykorzystano współczynniki zmienności (tab. 3) ${ }^{8}$.

\section{Tabela 3}

Współczynniki zmienności wydatków ubogich gospodarstw domowych w latach 1998-2001

\begin{tabular}{|l|c|c|c|}
\hline \multirow{2}{*}{ Wyszczególnienie } & \multicolumn{3}{|c|}{ Wartość współczynników zmienności w latach } \\
\cline { 2 - 4 } & 1998 & 1999 & 2001 \\
\hline Żywność & 0,194 & 0,121 & 0,125 \\
\hline Mieszkanie & 0,410 & 0,406 & 0,409 \\
\hline Koszty utrzymania mieszkania & 0,401 & 0,409 & 0,410 \\
\hline Odzież i obuwie & 0,450 & 0,483 & 0,497 \\
\hline Higiena osobista & 0,349 & 0,308 & 0,311 \\
\hline Ochrona zdrowia & 0,428 & 0,411 & 0,420 \\
\hline Edukacja & 0,465 & 0,432 & 0,432 \\
\hline Transport & 0,422 & 0,364 & 0,443 \\
\hline
\end{tabular}

Źródło: Obliczenia własne na podstawie: Warunki życia ludności. GUS, Warszawa, $1999,2000$.

\footnotetext{
${ }^{6}$ Sfera niedostatku obejmuje gospodarstwa domowe osiagające dochody poniżej minimum socjalnego.

${ }^{7}$ Obliczenia własne dla jednoosobowych gospodarstw domowych.

${ }^{8}$ Wspótczynnik zmienności wyraża stosunek odchylenia standardowego do średniej arytmetycz-

nej: $\left(V(x)=\frac{S(x)}{\bar{x}}\right)$, gdzie $S(x)$-odchylenie standardowe, $\bar{x}$-średnia arytmetyczna.

Wspólczynnik zmienności (V) jest miarq zróżnicowania zjawiska. Wraz ze wzrostem lub spadkiem wartości wspótczynnika rośnie lub maleje zróznicowanie. Inaczej ujmując, im większa wartość wskaśnika, tym większe zróżnicowanie [Kassyk-Rokicka H., „Statystyka nie jest trudna", PWN, Warszawa 1994].
} 
W 1998 r. najmniejsze zróżnicowanie charakteryzowało wydatki na żywność, a więc dobra niezbędne do zaspokojenia podstawowych potrzeb fizjologicznych człowieka. Wyższe były wartości współczynnika zmienności wydatków na mieszkanie i koszty jego utrzymania. Najwyższe wskaźniki zróżnicowania wykazywały wydatki na odzież i obuwie oraz na potrzeby natury kulturowej, zdrowotnej i społecznej.

W 1999 r. wartości współczynników zmienności kształtowały się na podobnym poziomie, $\mathrm{z}$ niewielkim jednak wzrostem zróżnicowania wydatków na żywność oraz odzież i obuwie. W 2001 r. wartości wszystkich współczynników zwiększyły się, co świadczy o wzroście zróżnicowania wydatków wśród gospodarstw domowych żyjących poniżej danej granicy ubóstwa.

Niski poziom dochodów uzyskiwanych przez rodzinę „wymusza” konieczność ukierunkowania wydatków na zaspokojenie podstawowych potrzeb, w tym przede wszystkim żywnościowych. W ogólnych wydatkach ubogich gospodarstw domowych dominująca pozycję zajmuje żywność i napoje bezalkoholowe (rys. 1). Na tę grupe potrzeb największą część wydatków (ponad $60 \%$ ) przeznaczały rodziny osiagające dochody poniżej minimum egzystencji. Gospodarstwa domowe żyjące poniżej relatywnej granicy ubóstwa wydawały na żywność 55\% swoich dochodów, natomiast rodziny żyjące w sferze ubóstwa materialnego przeznaczały na żywność $45 \%$ osiaganych dochodów. Oznacza to, że gospodarstwa domowe znajdujące się w ubóstwie skrajnym na żywność wydawały średnio o około $17 \%$ więcej od znajdujących się w ubóstwie materialnym oraz około $20 \%$ więcej od osób żyjących poniżej relatywnej granicy ubóstwa.

Jednym z wyznaczników głębokości ubóstwa gospodarstw domowych jest sposób odżywiania się, rozumiany jako regularność i jakość posiłków, a także często sytuacji, w których potrzeby żywieniowe rodziny nie są zaspokojone. Im częściej pojawia się w rodzinie głód bądź potrzeby żywieniowe nie są w pełni zaspokajane, tym większy jest stopień ubóstwa. W większości ubogich rodzin podstawą wszystkich posiłków są chleb i ziemniaki, często uzupełniane nabiałem (głównie mleko, sery i twarogi), rzadziej warzywami.

Występują zasadnicze różnice w poziomie konsumpcji żywności pomiędzy poszczególnymi granicami ubóstwa. W latach 1998-2001 ilość spożywanych artykułów żywnościowych ( $\mathrm{z}$ wyjattkiem pieczywa, tłuszczów roślinnych i mleka) w gospodarstwach domowych żyjących w skrajnym ubóstwie była dużo mniejsza niż w rodzinach żyjących powyżej minimum egzystencji, np.: spożycie warzyw o około $20 \%$, owoców i przetworów o około $35 \%$, ryb o $40 \%$, jogurtów prawie o $40 \%$, a serów o $20 \%{ }^{9}$.

\footnotetext{
${ }^{9}$ Warunki życia ludności. GUS, Warszawa 1999, 2000.
} 
Wyznacznikiem ubóstwa gospodarstw domowych jest też częstość spożywania mięsa. W najuboższych gospodarstwach domowych mięso jada się nie częściej niż raz w miesiącu, podczas gdy w najlepiej sytuowanych dwa, trzy, a nawet cztery razy w tygodniu. Rodziny żyjące w sferze niedostatku spożywają średnio o $20 \%$ więcej mięsa od osób znajdujących się poniżej minimum egzystencji i o $10 \%$ więcej od gospodarstw domowych znajdujacych się poniżej relatywnej granicy ubóstwa ${ }^{10}$.

Biorąc pod uwagę fakt, że ziemniaki, pieczywo i nabiał są podstawowymi składnikami diety ubogich gospodarstw domowych, w lepszej sytuacji są rodziny zamieszkujące tereny wiejskie. Dzieje się tak ze względu na możliwość samozaopatrzenia $z$ własnych działek, która jest dużo mniejsza w większych miastach. Własne zbiory z ogrodów, choć nie zaspokajają w pełni potrzeb rodziny, są istotnym elementem ułatwiającym utrzymanie, często zaś nawet jej przetrwanie.

Rodziny rolnicze spożywają znacznie więcej produktów o najmniejszym stopniu przetworzenia, takich ja mleko, mięso, słonina, warzywa i owoce. $\mathrm{Z}$ produktów przetworzonych dominują najtańsze garmażeryjne przetwory mięsne. W stosunkowo dobrej sytuacji znajdują się też rodziny, które prowadzą własne gospodarstwo rolne, oraz rodziny, którym pomagają krewni posiadający takie gospodarstwo. Nie należy jednak sądzić, że dzięki temu eliminowany jest problem ubóstwa wśród rodzin rolniczych. Jest to sposób zaspokajania tylko najważniejszej potrzeby tych rodzin. Rodziny drobnych rolników niejednokrotnie żyją w dramatycznych warunkach. Wprawdzie mogą korzystać z żywności produkowanej we własnych gospodarstwach, często jednak nie mają innych źródeł dochodu, a koszt produkcji niekiedy przewyższa wpływy ze sprzedaży towarów.

Do analizy spożycia żywności w rodzinach żyjących w sferze ubóstwa obliczono współczynniki zmienności spożycia podstawowych produktów żywnościowych w ujęciu ilościowym (tab. 4) ${ }^{11}$.

W odniesieniu do spożycia ilościowego podstawowych produktów żywnościowych wysokość dochodów miała największy wpływ na wielkość spożycia ryb, masła oraz jogurtów, mniejszy - na spożycie mięsa, serów i owoców, a najmniejszy na spożycie produktów spożywanych codziennie, tj. pieczywa, ziemniaków, mleka, serów.

\footnotetext{
${ }^{10}$ Jak wyżej.

${ }^{11}$ Wykorzystano ten sam wzór, co przy analizie zróżnicowania wydatków ubogich gospodarstw domowych.
} 
Tabela 4

Współczynniki zmienności spożycia ilościowego podstawowych produktów żywnościowych

\begin{tabular}{|l|c|c|c|}
\hline \multirow{2}{*}{ Wyszczególnienie } & \multicolumn{3}{|c|}{ Wartość współczynników zmienności w latach } \\
\cline { 2 - 4 } & 1998 & 1999 & 2001 \\
\hline Pieczywo & 0,012 & 0,026 & 0,031 \\
\hline Ziemniaki & 0,033 & 0,038 & 0,033 \\
\hline Rośliny strączkowe & 0,098 & 0,039 & 0,121 \\
\hline Owoce & 0,181 & 0,102 & 0,102 \\
\hline Mięso & 0,132 & 0,064 & 0,111 \\
\hline Ryby & 0,432 & 0,274 & 0,345 \\
\hline Masło & 0,238 & 0,169 & 0,198 \\
\hline Margaryna & 0,013 & 0,007 & 0,009 \\
\hline Mleko & 0,043 & 0,036 & 0,037 \\
\hline Jogurty & 0,392 & 0,207 & 0,231 \\
\hline Sery & 0,176 & 0,086 & 0,341 \\
\hline
\end{tabular}

Źródło: Obliczenia własne na podstawie: Warunki życia ludności. GUS, Warszawa 1999, 2000.

Analiza zestawienia różnic w spożyciu w wymiarze ilościowym pozwala wnioskować, że rodziny najuboższe kupują żywność tańsz̨̧, często o mniejszej wartości odżywczej, a ich wzorzec konsumpcji jest mało urozmaicony. Przedłużanie się takiej sytuacji może pociągać za sobą konsekwencje nie tylko zdrowotne, ale i natury psychicznej.

Drugą pozycję w strukturze wydatków ubogich gospodarstw domowych zajmuje utrzymanie mieszkania (rys. 1). Mieszkanie jest ważnym składnikiem majątku wszystkich gospodarstw domowych, a jego wyposażenie świadczy o pozycji majątkowej, stanie zamożności i poziomie osiagganych dochodów. Jest dobrem zaspokajającym podstawowe potrzeby całego gospodarstwa domowego i poszczególnych jego członków. Jest to miejsce życia całej rodziny, w którym zachodzą różnorodne procesy i realizowane sa poszczególne jej funkcje. Posiadanie własnego mieszkania umożliwia gospodarstwu lepszą realizację dochodów, zaspokajanie innych potrzeb, a także daje możliwość gromadzenia dóbr konsumpcyjnych trwałego użytku, składających się na majątek gospodarstwa domowego.

Jak wynika $z$ badań budżetów gospodarstw domowych przeprowadzonych przez GUS, istnieje ścisła zależność między stopniem ubóstwa gospodarstw domowych a stanem technicznym mieszkań. Im lepsza jest sytuacja materialna rodziny, tym lepszy jest stan techniczny jej mieszkania i tym większe są możliwości przeprowadzenia w nim remontu. Należy także zauważyć, że warunki mieszkaniowe (zarówno w domach wolno stojących, jak i w blokach) osób 
ubogich są o wiele gorsze na terenach wiejskich. Najbardziej zaniedbane mieszkania znajdują się w blokach należących do byłych państwowych gospodarstw rolnych.

W analizowanym okresie w gospodarstwach domowych żyjących poniżej określonej granicy ubóstwa na mieszkanie stosunkowo najwięcej przeznaczały rodziny żyjące w sferze niedostatku (20\% ogółu ponoszonych wydatków), o ponad $30 \%$ więcej od wydatków na utrzymanie mieszkania w rodzinach żyjących w warunkach poniżej standardu minimum egzystencji i o około $20 \%$ więcej niż w gospodarstwach poniżej relatywnej granicy ubóstwa (rys. 1).

Różnice w poziomie wydatków na mieszkanie pomiędzy poszczególnymi granicami ubóstwa wynikają m.in. $\mathrm{z}$ faktu, iż wydatki gospodarstw domowych żyjących $w$ sferze ubóstwa skrajnego $\mathrm{w}$ większym stopniu są pomniejszane ze względu na możliwość korzystania $\mathrm{z}$ dodatków mieszkaniowych $\mathrm{w}$ ramach pomocy społecznej. Ich mniejszy udział w strukturze wydatków może też wynikać z nieuiszczania stosownych opłat.

Skutkiem obciążenia budżetów rodzinnych wydatkami na ̇̇ywność i mieszkanie jest ograniczenie wydatków na zaspokojenie innych potrzeb. Są to przede wszystkim wydatki na odzież i obuwie. Większość rodzin stara się ograniczać wydatki na odzież, dokonując przede wszystkim zakupów w sklepach z używaną odzieża, poza tym odzież jest także przedmiotem wymiany między rodzinami. Znacznie poważniejszym wydatkiem w większości rodzin jest zakup obuwia, m.in. dlatego, że jest ono rzadkością w sklepach z używana odzieżą. W badanym okresie udział wydatków na odzież i obuwie przez ubogie rodziny zmniejszał się systematycznie o 1 punkt procentowy rocznie. Relatywnie najmniej na ten cel przeznaczały gospodarstwa domowe żyjące w skrajnym ubóstwie, prawie o $38 \%$ mniej w stosunku do osób o najmniejszym stopniu ubóstwa ${ }^{12}$.

Bardzo ważnym wskaźnikiem ubóstwa jest także wielkość wydatków na higienę osobistą i ochronę zdrowia. Im głębsze jest ubóstwo, tym większe występują braki w zaspokajaniu potrzeb, tym gorsze warunki życia i tym większe występuje zagrożenie zdrowia. Obserwowane jest znaczne pogorszenie stanu zdrowia nie tylko dorosłych, ale dzieci i młodzieży wynikające bardzo często $z$ niedożywienia i zaniedbania. To właśnie zaniedbanie jest zjawiskiem bardzo niepokojącym. Podobnie jak w przypadku wyżej wymienionych wydatków, na ochronę zdrowia osoby żyjące w warunkach poniżej minimum egzystencji ponoszą około 2,5\% ogółu wydatków. Dla porównania, gospodarstwa domowe żyjące sferze niedostatku na tę grupe potrzeb wydają o $63 \%$ więcej, a osoby żyjące poniżej relatywnej granicy ubóstwa o około $42 \%$ więcej $^{13}$.

\footnotetext{
${ }^{12}$ Warunki życia ludności. GUS, Warszawa 1999, 2000.

${ }^{13}$ Jak wyżej.
} 
Najmniejszy odsetek w strukturze wydatków ubogich gospodarstw domowych zajmuje edukacja - niewiele ponad 1 punkt procentowy rocznie ${ }^{14}$. Wraz $\mathrm{z}$ pogarszającą się sytuacją materialną zmniejsza się wartość edukacji w oczach rodziny, zwłaszcza jeśli rodzice zdobyli wykształcenie jedynie podstawowe lub niepełne podstawowe. Innymi powodami moga być także brak obuwia pozwalającego na uczęszczanie do szkoły, wymagania nauczycieli, co do wyposażenia, niedożywienie i trudne warunki życia. Konsekwencją tego jest fakt, że ludzie gorzej wykształceni wykazują większą nieporadność życiową a przyczyn swego ubóstwa upatruja głównie w cudzych błędach, systemie politycznym, działaniach rządu. Bardzo rzadko postrzegają własne zachowanie i postawy jako determinujące ich obecną sytuację.

\section{Wnioski}

Przeprowadzone badania pozwalają na sformułowanie następujących wniosków:

1. Ocena sfery ubóstwa wyłącznie ze względu na sytuację dochodową gospodarstw domowych jest dalece niewystarczająca. Włączenie do niej czynników pozadochodowych, charakteryzujących warunki mieszkaniowe oraz zasobność gospodarstw domowych, znacznie wzbogaca analizę w ujęciu klasycznym.

2. W latach 1998-2001 minimum socjalne dla l-osobowego gospodarstwa osoby do 60 . roku życia stanowiło średnio $110 \%$ przeciętnego dochodu rozporządzalnego ogółu gospodarstw domowych oraz przewyższało płace minimalną o ponad $30 \%$. Oznacza to, że do sfery ubóstwa wchodzą także osoby pracujące i uzyskujące dochody.

3. Gorsze wyposażenie gospodarstw domowych żyjących w sferze ubóstwa w dobra trwałego użytku oraz niski standard zajmowanych przez nie mieszkań mogą wskazywać na fakt, że ubóstwo przynajmniej części z tych rodzin nie wynika jedynie $z$ krótkotrwałego pogorszenia się sytuacji dochodowej, lecz nabiera bądź już nabrało cech trwałości, stając się tym samym coraz poważniejszym problemem społecznym.

4. Największe zróżnicowanie w poziomie wydatków ubogich gospodarstw domowych dotyczy kosztów ponoszonych na edukację, ochronę zdrowia oraz mieszkanie.

${ }^{14}$ Jak wyżej. 


\section{Literatura}

BYWALEC CZ., Poziom i struktura żywienia społeczeństwa polskiego w latach 80 . Wiadomości Statystyczne 1991, nr 12.

GUTKOWSKA K., Uwarunkowania konsumpcji w polskich gospodarstwach domowych, Wydawnictwo SGGW, Warszawa 2001.

KASSYK-ROKICKA H. Statystyka nie jest trudna, PWN, Warszawa 1994.

PALSKA H., Bieda i dostatek. O nowych stylach życia w Polsce w latach 90. IFiS PAN, Warszawa 2002.

PANEK T., Sfera niedostatku i jej determinanty w Polsce, Wiadomości Statystyczne, Warszawa 2001.

Roczniki Statystyczne. GUS, Warszawa.

Warunki życia ludności w 1995 r. Studia i Analizy Statystyczne. GUS, Warszawa 1996.

\section{Economic Conditions of Poor Households in Poland}

\section{Summary}

The aim of the paper was to analyse economic conditions of poor households in Poland. The research shows the diversity of incomes and expenses within the poor households.

The paper was prepared on the basis of the data collected by the Main Statistical Office (GUS). 
